\title{
Socio-economic Characteristics of Smallholder Potato Farmers in Mauche Ward of Nakuru County, Kenya
}

\author{
Rael Jepkemei Taiy ${ }^{1, *}$, Christopher Onyango ${ }^{2}$, Agnes Nkurumwa ${ }^{2}$, Kibet Ngetich $^{3}$ \\ ${ }^{1}$ Ministry of Agriculture, Livestock and Fisheries, Kenya \\ ${ }^{2}$ Department of Agricultural Education and Extension, Egerton University, Kenya \\ ${ }^{3}$ Department of Sociology and Anthropology, Egerton University, Kenya
}

Copyright@2017 by authors, all rights reserved. Authors agree that this article remains permanently open access under the terms of the Creative Commons Attribution License 4.0 International License

\begin{abstract}
Understanding the socio-economic characteristics of smallholder farmers is important as it provides the basis for addressing the myriad challenges that the farmers face. This study therefore was carried out to determine the socio-economic characteristics of smallholder potato farmers in Mauche Ward of Njoro Sub-County, Kenya. Simple Random sampling was used to select 150 smallholder potato farmers to participate in the household survey. A structured questionnaire was used to collect socio-economic data from the respondents. Data analysis was done using SPSS and results presented descriptively using frequencies, percentages, bar charts, means and standard deviation. The results indicate that most farmers have low education, mainly primary and secondary education and majority are relatively old. Though a high proportion of the farmers are married, cases of single farmers are common. Potato is a key crop but livestock keeping, particularly cattle and chicken are kept by almost all households. The study also revealed that smallholder farmers earn low income if they depend on on-farm activities alone. Potato farmers in Mauche have limited access to clean potato seed as many of them rely on seed purchased in open air markets and from other farmers. The major constraints to potato marketing are lack of collective action and low prices dictated by middlemen which translate to low farm incomes. Smallholder potato farmers need to increase their income by enhancing productivity through improved crop and land management practices. Engaging in profit oriented off-farm activities such as value addition may also enhance farmers' earnings. There is a need to capacity built farmers on clean potato seed production to ensure timely access to good quality seed at a more affordable price. Farmers need to form cooperative societies to enable them do collective marketing of their farm produce and purchase of farm inputs in order to benefit from the economies of scale.
\end{abstract}

Keywords Household, Incomes, Potato, Smallholder, Socio-economics

\section{Introduction}

Agriculture is the backbone of Kenya's economy and the means of livelihood for most of the rural population. The sector contributes directly 26 percent of the GDP and 25 percent indirectly. It supplies the manufacturing sector with raw materials and generates tax revenue that helps support the rest of the economy (GOK [1]). The sector also accounts for 65 percent of Kenya's total exports, employs over $40 \%$ of the population and supports the livelihood of over 70 percent of the rural population.

Currently, over ten million people in Kenya suffer from chronic food insecurity and poor nutrition, and between two and four million people require emergency food assistance at any given time. Nearly 30 percent of Kenya's children are classified as undernourished, and micronutrient deficiencies are widespread. It is the policy of the Government that all Kenyans throughout their life-cycle enjoy at all times safe food in sufficient quantity and quality to satisfy their nutritional needs for optimal health (GOK [2]).

Potato is the world's fourth largest food crop after wheat, rice and maize. It is an important food crop in Kenya, with production volumes only second to maize and plays a major role in national food and nutrition security (Muthoni \& Nyamongo [3]). Potatoes are an important source of food, employment and income in developing countries (Food and Agriculture Organization (FAO) [4]). The potato's high energy content and ease of production have also made it an important component of peri-urban agriculture which provides jobs and food security to some 800 million people globally (Hoffler and Ochieng [5]). Potatoes are grown and eaten locally, with little significant international trade compared to cereals, so they are particularly valuable as food in the developing countries. Potatoes mature in 3-4 months and can yield about 40 t/ha (FAO [4]) and hence ideally suited to places where land is limited and labour is abundant (FAO [4]). Kenya is the fifth biggest potato producer in 
Sub-Saharan Africa, with an output of more than one million tones cultivated by approximately 500,000 smallholder farmers (FAO [4]).

In Kenya, potatoes are mainly cultivated in the high altitude areas (1500-3000 metres above sea level) where maize, Kenya's main staple food has no comparative advantage (Kiiya, Mureithi \& Kiama [6]). These areas include the slopes of Mt. Kenya, the Mau escarpment, the Nandi escarpment, Cherangany hills and the slopes of Mount Elgon. Small acreages are also cultivated in Kericho, Kisii and isolated patches in the Taita hills (Kirumba, Kinyae \& Muchara [7]). Highland farmers can complete three planting seasons with potatoes (each season being 3-4 months long) unlike maize, which takes up to 10 months in these areas to mature. Potato thus becomes a steadier source of income and is planted both as a cash crop and staple food by farmers (Kiiya et al. [6]). At altitudes exceeding $2100 \mathrm{~m}$ above sea level, potatoes grow faster than maize and the total energy and protein production per hectare per day is higher for potatoes. Potatoes are often eaten with beans in most poor rural households during the 'hunger period' just before the maize crop matures in the long rains (Muthoni \& Nyamongo [3]).

The national average potato yield in Kenya has been reported at 7.5 tons per hectare (FAO [4]). This is far below the potential of 50 tons, largely due to poor husbandry practices such as low application of fertilizers and other production chemicals, inadequate quality seed and challenges associated with climate change (CIP [8]). Potato growers mostly use seed from their own harvest with higher disease levels, or purchase seed from a neighbor or the local market. Potato production is characterized by rapid and significant fluctuations in supply and demand. A majority of potato farmers depend on rain and produce potatoes twice a year due to bimodal rainfall patterns in most potato growing areas (Kaguongo et al [9]). Long rains occur in March to July while the short rains are received in October to December. Off-season potato production is limited to a few areas where there is irrigation.

The Kenyan potato value chain is characterized by seasonality in production and lack of on-farm ware potato storage. High transaction costs, price inefficiencies and quality losses lead to minimal returns to farmers (Kaguongo et al [9]). The market is controlled by cartels, which shield producers from receiving any market information. Due to the highly perishable nature of the potato, prices fall during the glut season, hence low net returns to farmers. Transportation of potatoes to the market is expensive due to poor road infrastructure in the producing areas (Hoeffler, [10]). Packaging of the potato in extended bags of 160 kilograms (kg) has led to exploitation of farmers by traders (Gathumbi, [11]). Potato chips and crisps production is a determining factor of growth in demand for potatoes (Eastern and Central Africa Programme for Agricultural Policy Analysis, [12]). Apart from households, other major potato consumers are canteens, hotels and restaurants. Potato chips are a common menu item in hotels and fast food restaurants. Understanding consumer preference helps to assess the real demand in terms of quantity and quality.

To strengthen the seed potato value chain, research should concentrate on more efficient and risk reducing methods of seed production as well as best agronomic measures like improvements in plant nutrition and disease control (International Potato Centre (CIP) [8]). Limited knowledge of good agricultural practices and climate variability lead to low yield, poor quality of ware potatoes and seasonality in production. Market inefficiencies characterized by a fragmented value chain with too many uncoordinated actors lead to poor farmer-market linkages. Lack of contractual agreement in supplies, integrated quality assurance and adequate information on handling skills result in low quality and unreliable supplies.

The socio-economic conditions of smallholder farmers need to be given adequate consideration. Where these conditions are poor, the farmers are unlikely to participate in development (Opara [13]). This study generated socioeconomic data to help smallholder potato farmers understand their key attributes and how they may enhance their potato production. The results may also assist planners and policy makers in formulating strategies to enhance potato production in the country. Researchers and extension service providers may use the results to strengthen linkages and hence flow of technologies to smallholder potato farmers.

\section{Materials and Methods}

\subsection{Study Area}

The study was carried out in Mauche Ward of Njoro Sub-County. Mauche lies in the Mau escarpment and covers an area of 166 square kilometers. Its altitude is $2100-2800 \mathrm{~m}$ above sea level and receives an annual rainfall of 1600-2200 $\mathrm{mm}$. The rainfall pattern is bimodal with the long rains received in March to August and short rains in October to December. Agro-ecological zones are Upper Highlands and Lower Highlands. Mauche has a population of 25,088 comprising of 4994 households and 5590 farm families (GOK [14]). The main crops grown in Mauche are Maize, Potato, wheat, beans and vegetables. Livestock kept include cattle, sheep and local chicken. The livelihoods of the people in the area vary, but the main income generating activities are livestock and crop farming. Off-farm activities include businesses and salaried employment. The main challenges to agricultural productivity include inadequate certified or clean potato seed, high cost of farm inputs, poor road network, crop pests and diseases as well as decreasing soil fertility levels which hamper realization of potential yields (GOK [14]). Figure 1 presents the location of the study area. 


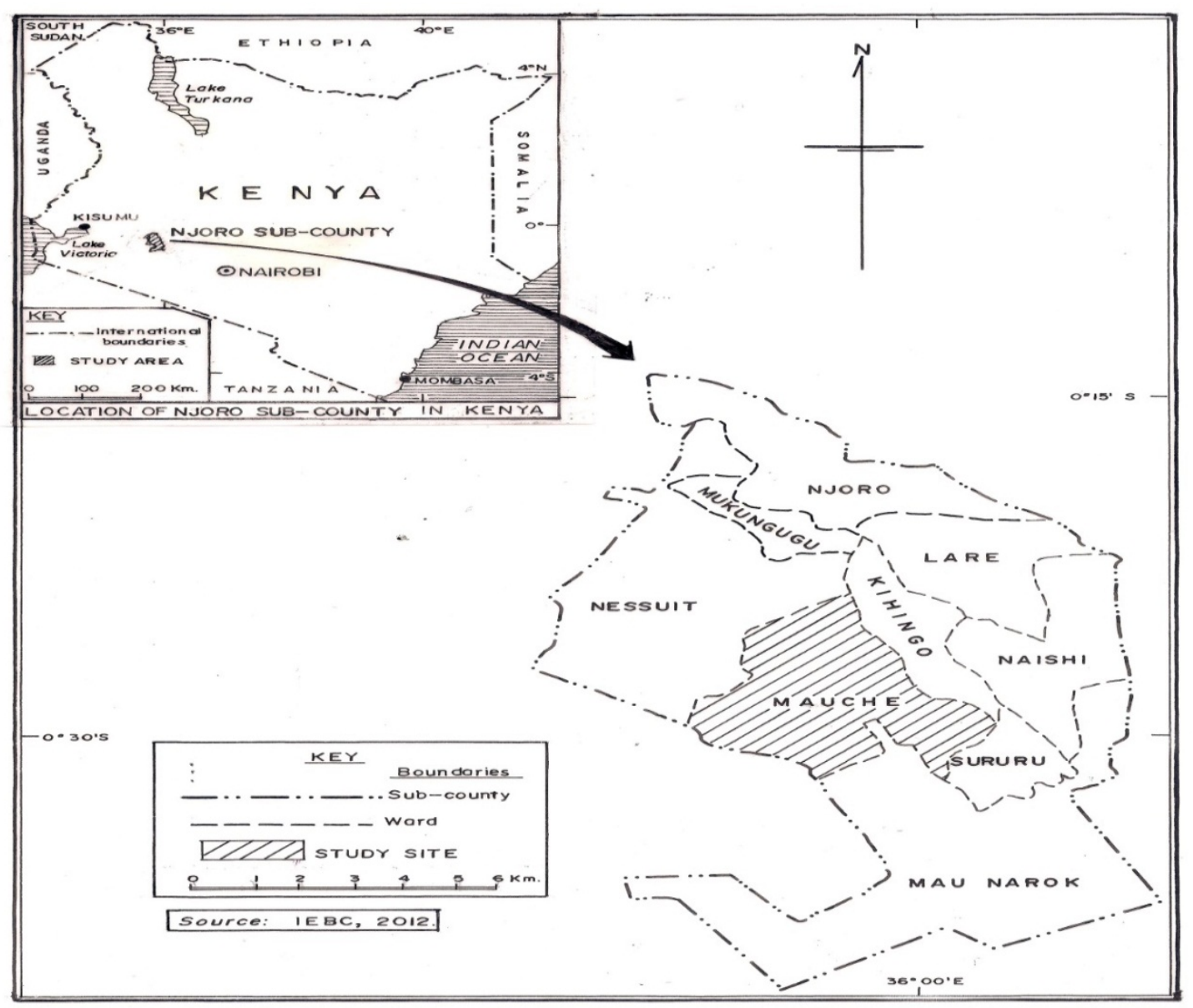

Figure 1. Location of the Study Area

\subsection{Data Collection}

The study employed Simple Random Sampling to select 150 farmers to participate in the household survey. A pre-tested semi-structured questionnaire to collect primary data from sampled smallholder farmers in the study area to elicit information on socio-economic characteristics such as gender, age, level of education, farming systems, household income and household practices. Collected data was edited, coded and analyzed using SPSS. The results were presented descriptively using frequency, percentages, bar charts, means and standard deviation. Purposive sampling was used to select 30 farmers to participate in 3 focus group discussions. Ten farmers were engaged in each focus group discussion to validate the household survey results.

\section{Results and Discussion}

\subsection{Age of the Respondents}

Age as a moderator variable was investigated as it has been found to affect farm level decisions and participation in group activities. The age categories of the potato growing farmers are presented in Figure 2.

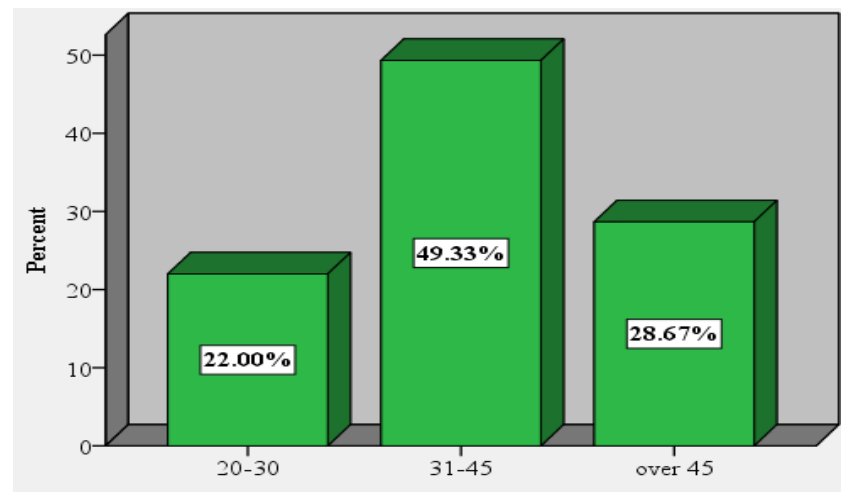

Figure 2. Age category of the respondents

A majority of the respondents (49.3\%) were in the age category between 31 and 45 years, which may be considered as the prime age for productivity. While working with peasant farmers in South-Western Nigeria, Ongusuni[15] found out that there is a positive relationship between age and adoption of technologies. Age of the household head predisposes a farmer to better farming techniques through "learning by doing" and better management skills (Khai et al [16]). Age is assumed to increase the probability of adoption but at a decreasing rate as the age increases. 


\subsection{Gender of the Respondents}

The sample population was selected with gender in mind in order to have representation in both the males and the female groups. The gender representation is given in Figure 3.

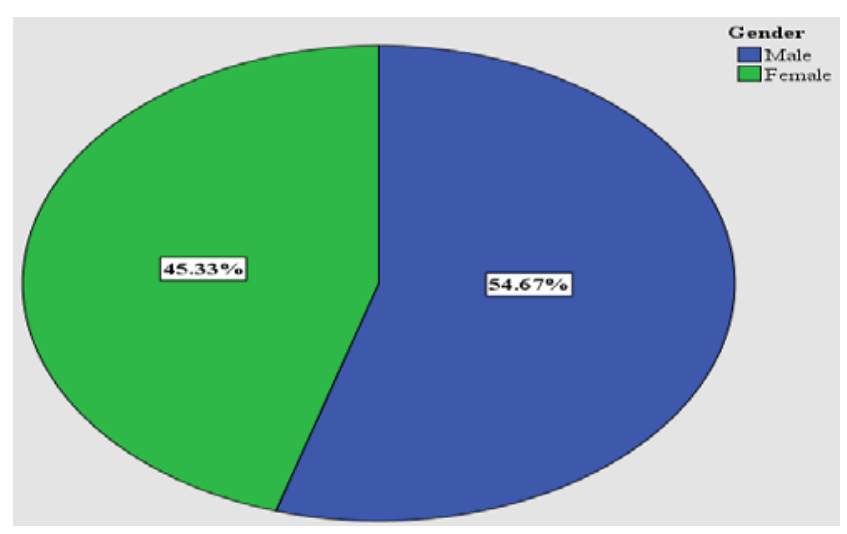

Figure 3. Gender of the respondents

The study sample was composed of more males than the females. This is a reflection of the situation in the study area where most of the households are headed by male and fewer by females. The number of male respondents was 82 which represented 54.7 per cent of the sample as compared to 68 females representing 45.3 per cent. The respondents were largely household heads, hence the higher male representation. Gender has been known to influence agricultural production through issues and concerns that surround access and control of resources for production. Men as heads of households have greater access to land, credit and extension services (GoK [17]). Male dominance in decision making in the household and economy has continued even in areas where women are the key providers of labour because the influence of women has rarely been recognized (Damisa \&Yohanna [18]). Females constitute a small portion of land owners though they provide the bulk of farm labour.

\subsection{Respondent's Relationship to the Household Head}

The respondents were asked to state their relationship to the household head, in order to determine whether the respondents were also the owners of the farms they were living in. The responses are given in Table 1.

Table 1. Relationship of respondents to household head

\begin{tabular}{|c|c|c|}
\hline Relationship & Frequency & Percent \\
\hline Self & 87 & 58.0 \\
\hline Wife & 52 & 34.7 \\
\hline Son & 5 & 3.3 \\
\hline Relative & 3 & 2.0 \\
\hline House help & 3 & 2.0 \\
\hline Total & $\mathbf{1 5 0}$ & $\mathbf{1 0 0 . 0}$ \\
\hline
\end{tabular}

The results in Table show the survey was well conducted since the enumerators to a large extent met the household head $(58 \%)$ or the wife (34.7\%). This implies a greater reliability of data since the targeted respondents were met.

\subsection{Male and Female Headed Households}

The household head is mainly responsible for the economic wellbeing of the household. Table 2 presents the respondents' relationship to the household heads in relation to gender.

Male headed households were found to be more common (55\%) in the study area than the female headed households (38\%). The World Bank [19] defines delegate heads as women whose husbands are often away and who therefore have substantial but not total responsibility for the household. In this study, the delegate household heads accounted for 34.7 per cent whereas female headed households accounted for 3.3 per cent of the sample.

Table 2. Comparison of household head and gender

\begin{tabular}{|c|c|c|c|c|c|c|}
\hline \multirow{3}{*}{$\begin{array}{l}\text { Relationship of respondent } \\
\text { to Household head }\end{array}$} & \multicolumn{4}{|c|}{ Gender of the farmer } & \multirow{2}{*}{\multicolumn{2}{|c|}{ Total }} \\
\hline & \multicolumn{2}{|c|}{ Male } & \multicolumn{2}{|c|}{ Female } & & \\
\hline & No & $\%$ & No & $\%$ & No & $\%$ \\
\hline Self & 84 & 56 & 5 & 3.3 & 89 & 59.3 \\
\hline wife & 0 & 0 & 52 & 34.7 & 52 & 34.7 \\
\hline son & 5 & 3.3 & 0 & & 5 & 3.3 \\
\hline Relative & 3 & 2.0 & 0 & 0 & 3 & 2.0 \\
\hline House help & 1 & 0.7 & 0 & 0 & 1 & 2.0 \\
\hline Total & 93 & 62 & 57 & 38 & 150 & 100.0 \\
\hline
\end{tabular}


The figures in Table 2 show a marked increase in the number of the female headed households from 23 to 38 per cent, when compared to the Kenya Integrated Household Budget Survey (KNBS) in the region (KNBS [20]). The increase could be attributed to the increased number of widows in the area, which was estimated at 16 per cent (KNBS [20]). The female-run households add up to 38 per cent, when households headed by delegate heads and women are considered together. The figure is critical especially in a patriarchal society (like the case with the Kalenjin community found in the area) where major decisions are made by the males.

Female household heads relative to male household heads have limited access to protective social networks (Flato, Muttarak \&Pelser, [21]), education attainment (FAO, [22]), access to assets and services (Kassie, Ndiritu \& Stage, [23]). Gender of the household head affects both the manner in which household resources are utilized and distributed within the household (Kamau, Kimani \& Wamae-Ngare, [24]).

\subsection{Education Level of the Farmers}

The education level is an important factor in this study because the activities related to the mitigation of climate change need some level of understanding. The farmers were asked to state their highest level of formal education they had attained and the results are given in Figure 4.

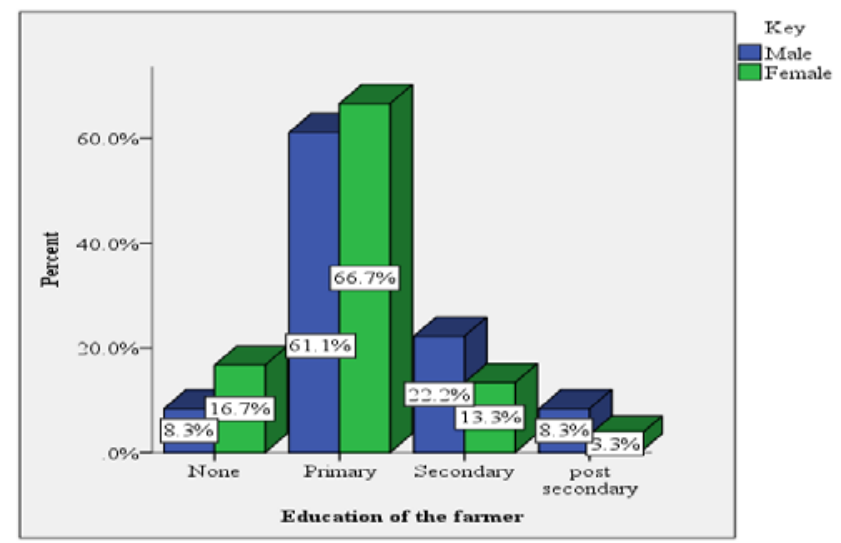

Figure 4. Education level of the respondents differentiated according to gender

More than half of the farmers (66\% male and 61\% Female) had completed the primary level of formal education, meaning that they were able to read and write and understand many of the concepts primary to this study. There were more males with secondary education at 22.2 per cent and post-secondary education at 8.3 per cent than females with 13.3 per cent and 3.3 per cent. As suggested by Balakrishnan [25], there is an important link between education level, personal empowerment to escape poverty, possession of appropriate information and making of informed choices. Farmers with higher levels of education tend to be more efficient in production. As noted by Nyagaka, Obare and
Nguyo [26], better performance by more educated farmers may be attributed to the fact that education gives the farmers the ability to perceive, interpret and respond to new information and improved technology such as fertilizers, pesticides and planting materials much faster than their counterparts.

\subsection{Farming System}

The farming system practiced by the sampled respondents in the study area is described using the following factors: (i) Farm size (ii) Land tenure, (iii) Crops grown and (iv) Livestock kept.

\subsubsection{Farm Size Owned by the Respondents}

The size of farm owned by the farmers is an important asset in that it determines the farming system that can be applied and output that can be obtained from the land. A majority of the farmers (59.3\%) owned farms that ranged in size between 0.6 and 2 hectares, while 24.7 percent of the farmers owned 0.1 to 0.5 hectares. Only 16 percent of them owned farms that ranged between 2.1 to 4 hectares. According to FAO [27], small farm households work on land smaller than 2 hectares. Many are poor and food insecure with limited access to markets and services. Farm sizes are known to determine production levels (Ojango \& Pollot [28]). Farm size is a direct positive correlate of productivity as it offers the farmer endowment with productive assets. Farmers with relatively large holdings are expected to benefit from the economies of scale.

\subsubsection{Land Tenure}

The type of land ownership determines the type of innovations and developments that a farmer will initiate on his land. The farmers who own the land will be willing to initiate permanent long term activities on their pieces of land. The type of tenure existing in the study area is summarized in Table 3.

Table 3. Land tenure system in the study area

\begin{tabular}{|c|c|c|}
\hline Tenure & Frequency & Percent \\
\hline Owned with title deed & 75 & 50.0 \\
\hline Owned without title deed & 64 & 42.7 \\
\hline Rented & 9 & 6.0 \\
\hline Owned by Parents/Relatives & 2 & 1.3 \\
\hline Total & 150 & 100.0 \\
\hline
\end{tabular}

Two main forms of land tenure were captured in the study. The respondents either owned land with title deeds (50 \%) or owned land without title deeds (42.7\%), while 7.3 per cent did not own the land they were using to grow potatoes. Farmers' ability to obtain credit may be correlated with land tenure (Ado-Nyako \& Lele [29]). It may be difficult for a farmer whose land is not titled to obtain credit, which is common for many smallholders. 
Table 4. Types of crops grown and farm size allocated

\begin{tabular}{|c|c|c|c|c|c|c|c|c|}
\hline \multicolumn{9}{|c|}{ Farm size (Hectares) } \\
\hline \multirow{2}{*}{ Crop } & \multicolumn{2}{|c|}{0 (None) } & \multicolumn{2}{|c|}{$0.1-0.5$} & \multicolumn{2}{|c|}{$0.6-2$} & \multicolumn{2}{|c|}{$2.1-4$} \\
\hline & $\mathrm{f}$ & $\%$ & $\mathrm{f}$ & $\%$ & $\mathrm{f}$ & $\%$ & $\mathrm{f}$ & $\%$ \\
\hline Maize & 0 & 0 & 107 & 71.3 & 41 & 27.3 & 2 & 1.3 \\
\hline Potatoes & 0 & 0 & 132 & 88 & 15 & 10.0 & 3 & 2.0 \\
\hline Beans & 66 & 44 & 75 & 50.0 & 6 & 4.0 & 3 & 2.0 \\
\hline Vegetables & 75 & 50 & 75 & 50.0 & 0 & 0 & 0 & 0 \\
\hline Garden Peas & 58 & 38.7 & 92 & 61.3 & 0 & 0 & 0 & 0 \\
\hline
\end{tabular}

$\mathrm{N}=150$

iv) Crops Grown by the Respondents

The respondents grew five different types of crops on their farms, which included maize, potatoes, beans, vegetables and garden peas. The area allocated for each crop and the frequency of the respondents growing the crop is given in Table 4.

Main crops grown by the respondents included Maize, potato, beans, garden peas and vegetables. The majority of the respondents grew potatoes $(88 \%)$ and maize $(71 \%)$ on land size between 0.1 and 0.5 hectares. This means that potatoes and maize are grown on majority of the small scale farms in the area. Crop diversification improves household food security since different crops are affected differently by the same climatic conditions (Mutekwa [30]). In addition, it is a strategy for enhancing the welfare of low-income rural households, mitigation of risk, employment generation and conservation of biodiversity (FAO [31]). The possibility of interruption in insect and diseases cycles and utilization of resources make the diversified system more preferable compared to the monocrop production system.

\section{v) Livestock Kept by the Respondents}

Five different types of livestock were kept by the farmers, these included: Cattle, sheep, goats, chicken, and bees. Farmers kept more than one type of animal. The type and number of animals kept by the farmers is given in Table 5 .

Table 5. Type and number of livestock kept by the farmers

\begin{tabular}{|c|c|c|c|c|}
\hline \multirow{2}{*}{ Livestock } & \multicolumn{4}{|c|}{ Number of animals } \\
\cline { 2 - 5 } & $\begin{array}{c}\text { None (0) } \\
(\%)\end{array}$ & $\begin{array}{c}1-5 \\
(\%)\end{array}$ & $\begin{array}{c}6-10 \\
(\%)\end{array}$ & $\begin{array}{c}\text { Above 10 } \\
(\%)\end{array}$ \\
\hline Cattle & 7.6 & 86.4 & 6.1 & 0 \\
\hline Sheep & 53.0 & 39.4 & 6.1 & 1.5 \\
\hline Goats & 74.2 & 22.7 & 3.0 & 0 \\
\hline Chicken & 19.7 & 39.4 & 18.2 & 22.7 \\
\hline Bee hives & 83.3 & 10.6 & 4.5 & 1.5 \\
\hline
\end{tabular}

A majority (92.5\%) of the farmers kept cattle, followed by chicken by (80.3\%) and sheep (47\%). There were fewer farmers that kept goats (25.7\%) and bees (16\%). The climate of Mauche is too cold and therefore less suited to the keeping of goats. Farm level climate change adaptation strategies entail establishing crop/livestock mixed systems (Ayanwuyi, Kuponiyi, Ogunlade \& Oyetoro [32]). The people in this study area generally exhibited this trend.

\section{vi) Farmers' Income and Sources of Income}

Information on total income was gathered from respondents in order to gauge variations existing within the households. Income earned by the farmers is crucial as it determines the investments the farmers can initiate. The sources and the amount of income earned by the farmers are summarized in Table 6.

The farmers relied on six different sources of income, which could be classified into two main categories: farm income and non-farm income. Farm income included income from livestock and crops, while non-farm income included incomes from employment salary, small scale business and relatives. Income from the farm formed the highest portion of the farmer's income.

Farmers earning between K.Shs 50,000 and 70,000 annually formed 34.8 per cent of the respondents, followed by the farmers that earned between K.Shs 30,000 and 50,000 who formed 31.8 per cent of the sampled households. The farmers who earned less than K.Shs 10,000 (9.1\%) had low income and could be considered to be poor. From the feedback session with farmers, it came out clearly that farmers do not cost the food consumed in the households which is largely produced on the farm and hence perceived as free. According to Diiro [33], off-farm earnings may induce technology adoption by providing farmers with capital for purchasing inputs. 
Table 6. Sources and amounts of income

\begin{tabular}{|c|c|c|c|c|c|c|}
\hline \multirow{2}{*}{ Income sources } & \multicolumn{7}{|c|}{ Income categories (K.Shs) } \\
\cline { 2 - 8 } & $\begin{array}{c}\text { None } \\
(\%)\end{array}$ & $\begin{array}{c}<10,000 \\
(\%)\end{array}$ & $\begin{array}{c}10,000-30,000 \\
(\%)\end{array}$ & $\begin{array}{c}30,001-50,000 \\
(\%)\end{array}$ & $\begin{array}{c}50,001-70,000 \\
(\%)\end{array}$ & $\begin{array}{c}\text { Over 70,001 } \\
(\%)\end{array}$ \\
\hline Livestock & 13.6 & 7.6 & 40.9 & 22.7 & 4.5 & 10.6 \\
\hline Crop & 0 & 3.0 & 33.3 & 22.7 & 10.6 & 0 \\
\hline Salary & 92.5 & 1.5 & 1.5 & 0 & 0 & 4.5 \\
\hline $\begin{array}{c}\text { Small scale } \\
\text { business }\end{array}$ & 77.3 & 6.1 & 10.6 & 1.5 & 0 & 4.5 \\
\hline $\begin{array}{c}\text { Relatives / lenders } \\
\text { Others }\end{array}$ & 90.9 & 4.5 & 4.5 & 0 & 0 & 0 \\
\hline Total & 97.0 & 1.5 & 1.5 & 0 & 34.8 & 4.5 \\
\hline
\end{tabular}

\subsection{Analysis of Household Practices of Smallholder Potato Farmers}

The study investigated household practices of sampled smallholder potato farmers with specific focus on: (i) Access to potato seed (ii) Motivation for growing potatoes (iii) Potato storage (iv) Household food sufficiency (v) Potato consumption at household level (vi) Potato marketing (vii) Water conservation (viii) Sources of household energy

\subsubsection{Access to Potato Seed}

Access to potato seed by the farmers was assessed based on the source of seed and availability to the farmers. Source of quality and certified potato seeds was a major constraint in Mauche Ward. There was no structured seed supply and distribution system. A majority of the farmers (47.3\%) identified open air markets as their main source of potato seed (Plate 1). Farmers saving their own seed accounted for 34.7 percent whereas 8 percent acquired seed through their self-help group. Farmer-to-farmer exchange of seed accounted for 6 percent. Research centres such as KALRO and the Agricultural Development Corporation (ADC) Molo which is a major seed multiplier in the region supplied seed to 2 percent of the respondents each.

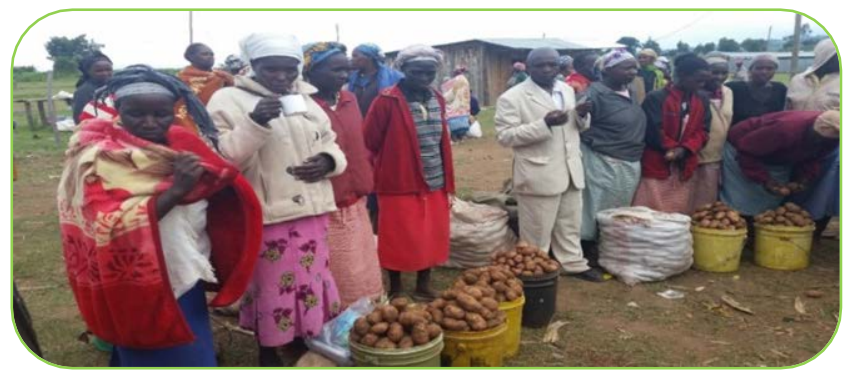

Plate 1. Open air potato market at Mauche

During the focus group discussion, it became clear that farmers mainly planted seed from unknown market sources or saved their own seed. This is a common occurrence in other parts of the country (Muthoni, Shimelis \&Melis [34]) and in the Eastern Africa region (CIP [8]). In Kenya, Uganda and Ethiopia farmers are known to renew their seeds after six, seven and three seasons respectively (Gildemacher [35]).Because of inadequate clean seed, most of the seed planted by the farmers is not certified and the quality is not guaranteed (Gaur [36]), hence the potential risk of introducing pathogens or pests (Pandey [37]).

Availability of seed was a major issue. Farmers who obtained potato seed in the quantities required every year constituted 53.3 percent of the respondents compared to 46.7 percent who did not. High price of potato seed and unavailability of seed at the right time were cited as the main reasons for not getting the right quantities of seed.

\subsubsection{Motivation for Growing Potatoes}

The study further attempted to understand what motivates the farmers to grow potato given that Mauche is a high potential area and a wide variety of crops can do well. A majority of the respondents were motivated to grow potato due to high consumer demand $(80.7 \%)$ as well as demand for potato seed (15.3\%). Potato is grown in Mauche mainly as a cash crop to enable the households to meet their financial obligations. The staple food crop in the area is maize. During the feedback session, farmers indicated that the main variety of potato grown is Shangi. Tigoni and Kenya Mpya are grown to a limited extent. Their choice of shangi is determined by yield, maturity time, marketability, disease resistance and taste. The choice of Shangi due to early maturity is considered as important for food security and income generation to meet farmers' financial obligations. Early harvesting allows up to three crop cycles within a year.

\subsubsection{Potato Storage}

Majority of the farmers (65.3\%) indicated that they store their potato seed by spreading it on dry grass in the store, 21.2 percent said that they kept the potato seed in bags in darkness while 10.6 percent said that they spread the seed on the floor under shed. On the other hand, potato for household consumption was spread on dry grass in the store by 54.7 percent of the respondents; 21.2 percent kept it in bags while 19.7 percent of them just left the potatoes in the farm and removed it whenever they needed to use it.

Mauche farmers have multi-purpose stores that cater for 
all household items including farm implements and bicycles. Appropriate potato storage using locally available materials has been a major area of focus during the farmers' trainings. Although potato is a perishable commodity, good storage can be a climate change adaptation strategy as it ensures continuous availability of ware potato as well as seed. Appropriate storage is necessary to maintain good quality of potato, which is an important factor in optimizing productivity (Biniam [38]). It is requisite for food security. As noted by Bouis [39], climate change affects all four dimensions of food security namely: food availability, stability of food supplies, access to food and food utilization.

\subsubsection{Household Food Sufficiency}

Household food sufficiency was chosen as a parameter to measure availability of food in the right quantity and quality. Food insecurity and food shortages are often experienced by poor people living in rural communities either during parts of the year or throughout the entire year.

Table 7 is the crop calendar for Mauche Ward as illustrated by the farmers.

Table 7. Crop calendar for Mauche Ward
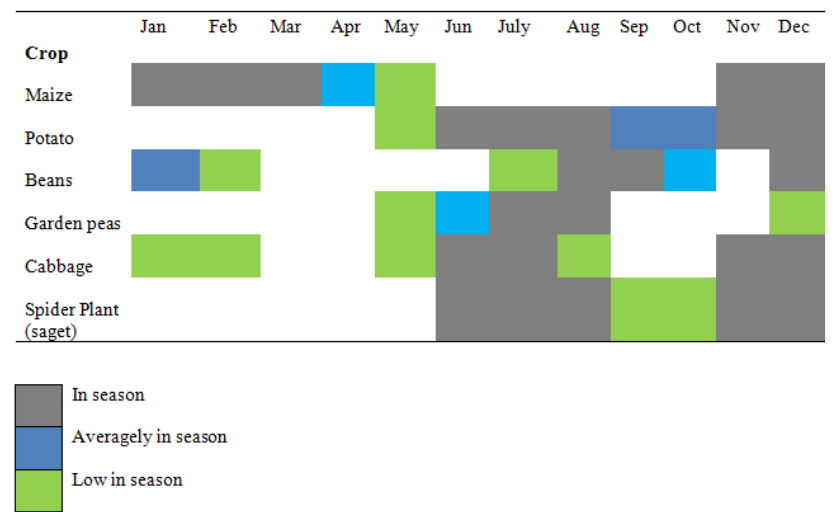

Farmers claiming that their households have sufficient food were 60.7 percent while 39.3 percent do not have sufficient food. During the feedback session with the farmers, household food insufficiency was mainly attributed to low yields due to soil degradation and post-harvest loses as a result of inadequate storage. These may be addressed by crop rotation or inter-cropping with nitrogen fixing crops as well as construction of adequate stores at farm level. The farmers clarified that in most cases what is perceived as shortage of food refers to shortage of maize since it is a staple food in the study area. Shortage of maize is common during the months of June to October when potato, beans, garden peas and vegetables such as cabbage and spider plant are in abundance.

Potato is a special staple food crop in several communities in Kenya, only second to maize (Muthoni \& Nyamongo [3]). The respondents were asked whether they use potato as a major food item in the household. The study revealed that 77.3 per cent of the farms use potatoes in their households. The farmers not utilizing potatoes cited various reasons which included low preference for potato as food, preference to sell it as a cash crop and lack of knowledge and skills on how to prepare food recipes from potato.

\subsubsection{Potato Marketing}

Integration of climate change adaptation strategies in potato production must be supported by a structured marketing system that enables farmers get better returns on their investment. To gain a better understanding of the marketing of potatoes, the respondents were asked if they had any constraints in marketing their potato. A significantly large number of farmers (89.3\%) responded that they had constraints in marketing their potato while only 10.7 percent reported having none. The farmers were asked to either agree or disagree with statements relating to the different constraints to the marketing of potatoes using a 5-point Likert scale. The farmers' responses to eight statements on potato growing constraints are given in Table 8 .

Table 8. Constraints to potato marketing

\begin{tabular}{|c|c|c|}
\hline & Mean & Std. Deviation \\
\hline Low quality of produce & 3.6 & 1.2 \\
\hline Low market prices & 4.4 & 0.6 \\
\hline Poor linkage to the market & 3.5 & 1.2 \\
\hline Lack of marketing information & 3.8 & 1.1 \\
\hline Difficulty in processing & 4.0 & 1.1 \\
\hline Difficulty in storage & 3.5 & 1.3 \\
\hline Poor transportation to market & 4.0 & 1.1 \\
\hline Farmers not organized to market \\
collectively & 4.4 & 0.8 \\
\hline N=150 & & \\
\hline
\end{tabular}

Farmers in Mauche are prone to exploitation by potato cartels that pay low prices for potatoes in extended bags. During the feedback session, farmers complained that traders extend the $110 \mathrm{~kg}$ bag to $160 \mathrm{~kg}$ and the $50 \mathrm{~kg}$ bag to $80 \mathrm{~kg}$. Due to lack of collective marketing by the farmers they are not able to bargain for better prices. Lack of cold storage in Mauche aggravates the situation as potato is a highly perishable produce hence farmers are forced to dispose of the produce immediately after harvesting.

\subsubsection{Sources of Household Energy}

Source of household energy is important in gauging the climate change adaptive capacity of the farmers. The respondents were asked to indicate their sources of energy in the household. Fuel wood was the main source of energy for the households in Mauche (100\%). Very few respondents substituted fuel wood with cooking gas (9.3\%). Solar energy was used by 5.3 percent respondents mainly for lighting. Use of charcoal and electricity are limited due to deforestation and inadequate electricity connectivity in Mauche. Dependence of fuel wood aggravates depletion of the tree cover in Mauche and this has contributed to climate variability and climate change. 


\section{Conclusions and Recommendations}

Smallholder farmers earn low income if they depend on on-farm activities alone. There is need to enhancing productivity by practicing proper crop intensification as well as soil and land management practices such as crop rotation, intercropping potato with legumes and practicing organic farming. Engaging in profit oriented off-farm activities such as value addition may also enhance farmers' earnings.

Potato farmers in Mauche have limited access to clean potato seed as many of them rely on seed purchased in open air markets or from other farmers. There is a need to capacity built smallholder farmers on clean potato seed production in order to bridge the existing deficit. This would ensure timely access clean potato seed by farmers at a more affordable price.

The major constraints to potato marketing are lack of collective action and low prices dictated by middlemen operating in Mauche area. Individual marketing has rendered farmers vulnerable to cartels that control prices and purchase potatoes in extended bags. Smallholder farmers need to form cooperative societies to enable them do collective marketing of their farm produce and purchase of farm inputs. This will enable them benefit from the economies of scale and address the issue of exploitation by middlemen.

Many farmers do not harvest rain water for domestic use and irrigation although Mauche lies in the high rainfall Mau escarpment. Farmers should be encouraged to harvest rain water for domestic use as well as irrigation. The County Government of Nakuru and other stakeholders need to factor in water harvesting infrastructure in Mauche area to satisfy water demand for domestic use and irrigation.

Firewood is the major source of energy in all households in Mauche due as it is more compared to other energy sources. Farm forestry should be promoted in Mauche for supply of firewood. This will also help restore the depleted tree cover in the area and enable farmers accessing timber for other uses on the farm as well as income generation.

\section{Acknowledgements}

The authors acknowledge the financial support of Egerton University, Kenya; University of Natural Resources and Life Sciences, Austria and University of Hohenheim, Germany through Smallholder Farmer Strategies to Cope with Climate Change (SMACC) project.

\section{REFERENCES}

[1] Government of Kenya (2010): Agricultural Sector Development Support Programme - Programme Document. Government Printer, Nairobi.

[2] Government of Kenya (2011): Food and Nutrition Policy.
Government Printer, Nairobi.

[3] Muthoni J. and Nyamongo D. O. (2009). A review of constraints to ware Irish potatoes production in Kenya. Journal of Horticulture and Forestry Vol. 1(7) pp. 098-102.

[4] Food and Agriculture Organization of the United Nations (2008). International Year of the Potato. Retrieved from www.potato2008.org.

[5] Höffler H. and Ochieng B.W.O. (2009). High commodity prices - who gets the money? A case study on the impact of high food and factor prices on Kenyan farmers. Berlin, Heinrich-Boell Foundation (available at http://www. boell.de/downloads/worldwide/ High Food Prices-Who GetsTheMoney_Kenya.pdf).

[6] Kiiya W.W., Mureithi J.G. and Kiama J.M. (2006). Improving production of Irish potato (Solanum tuberosum, L.) in Kenya: The use of green manurelegumes for soil fertility Improvement .In: Development and upscaling of Green manure legumes Technologies in Kenya. JGMureithi, CKK Gachene, JW Wamuongo and Eilitta M. (eds). KARI

[7] Kirumba W., Kinyae P. and Muchara M. (2004). Irish Potato Market. Survey Promotion of Private Sector Development in Agriculture. GTZ/MOA

[8] International Potato Center (CIP). 2011. Roadmap for investment in the seed potato value chain in eastern Africa. Lima, Peru, 27pp

[9] Kaguongo W.P., Gildemacher P., Demo P., Wagoire W., Kinyae P., Andrade J., Forbes G., Fuglie K. and Thiele G. (2008). Framer practices and adoption of improved potato varieties in Kenya and Uganda. International Potato Center (CIP) Lima, Peru. Social Sciences Working Paper 2008-5. 85p.

[10] Hoeffler H. (2005). Promoting The Kenyan Potato Value Chain: Can Contract Farming Help Build Trust and Reduce Transaction Risks? Paper prepared for presentation at the 99th EAAE Seminar 'Trust and Risks in Business Networks, February 8-10, 2006, Bonn, Germany

[11] Gathumbi M. (2009). Mainstream the potato. Paper Presented to the Irish Potato Round Table Meeting at Silver Springs Hotel Nairobi on May 8, 2009.

[12] Eastern and Central Africa Programme for Agricultural Policy Analysis (2006). Promoting Agricultural Value Chains: The Case of Kenya. ECAPAPA Newsletter Vol.9 No. 24.

[13] Opara U.N. (2010). Personal and Socio-Economic Determinants of Agricultural Information Use by Farmers in the Agricultural Development Programme (ADP) Zones of Imo State, Nigeria. Library Philosophy and Practice (e-journal). Paper 434.

[14] Government of Kenya (2014). Ministry of Agriculture, Livestock Development and Fisheries: Annual Report for Mauche Ward - 2013/2014 Financial Year.

[15] Ongusumi L.O. (2007). Socio-economic Conditions of Peasant Farmers: The Case of Agricultural Technologies Sustainability in South-West Nigeria. African Journal of Agricultural Research Vol 2 (9) pp. 441 - 446, September 2007.

[16] Khai, H.V., Yabe, M., Yokogawa, H., and Sato, G. (2008). Analysis of Productive Efficiency of Soybean Production in 
the Mekong River Delta of Viet Nam. Journal of Agriculture, Kyushu University. 53(1):271-279.

[17] GOK (2004). Strategy for Revitalizing Agriculture. Kilimo House; Nairobi, Kenya

[18] Damisa M.A. and Yohanna M. (2007). The Role of Women in Farm Management Decision Making Process: Ordered Probit Analysis. World Journal of Agricultural Sciences 3 (4): 543 547

[19] World Bank (1989). Women and Food Security in Kenya. Population and Human Resources Department: The World Bank, Washington D.C.

[20] Kenya National Bureau of Statistics (2008). Economic Survey 2008. Herufi House, Nairobi, Kenya

[21] Kamau P.W., Kimani E. and Wamue-Ngare G. (2014). Gender relattions in utilization of micro-finance resources among women in Kiharu Constituency, Murang'a County, Kenya. Merit Research Journal of Art, Social Science and Humanities, Vol. 2(7) pp.095-100, September, 2014.

[22] Food and Agricultural Organization, 2014. Tanzania Mainland country profile: gender inequalities in rural employment in Tanzania Mainland, an overview. FAO, Rome.

[23] Flato M., Muttarak R. and Pelser A. (2017). Weather and Woes: The Triangular Dynamics of Female-Headed Households, Economic Variability and Climate Variability in South Africa. World Development Vol. 90 pp. 41-62.

[24] Kassei M., Ndiritu S.W. and Stage J. (2014). What determines Gender Inequality in Household Food Security in Kenya? Application of Switching Treatment Regression. World Development Vol 56 pp. 153-171.

[25] Balakrishnan R. (2001). Gender Constraints to Rural Poverty Alleviation. New Delhi: FAO, India.

[26] Nyangaka D.O., Obare G.A. and Nguyo W. (2009). Economic Efficiency of Smallholder Irish Potato Producers in Kenya: A Case of Nyandarua North District. Contributed Paper prepared for presentation at the International Association of Agricultural Economists' Conference, Beijing, China, August 16-22, 2009.

[27] Food and Agriculture Organization of the United Nations. The economic lives of smallholder farmers. An analysis based on household data from nine countries. FAO, Rome.

[28] Ojango J.M.K. and Pollot, G.E. (2002). The relationship between Holstein bull breeding values for milk yield derived in both the U.K. and Kenya. Livestock Production Science, 74, $1-12$.
[29] Ado-Nyako K. and Lele U. (1992). Approaches to uprooting Poverty in Africa. Paper prepared for the annual meeting of the African Development Bank Group, Abidjan, Cote D’Ivoire.

[30] Mutekwa V.T. (2009). Climate Change Impacts and Adaptation in the Agricultural Sector: The Case of Smallholder Farmers in Zimbabwe. Journal of Sustainable Development in Africa, Volume 11, No.2.

[31] Food and Agriculture Organization (2013). A policymakers' guide to crop diversification: The case of the potato in Kenya. Food and Agriculture Organization of the United Nations, Rome.

[32] Ayanwuyi E., Kuponiyi F. A., Ogunlade I. and Oyetoro J. O. (2010). Farmers Perception of Impact of Climate Changes on Food Crop Production in Ogbomoso Agricultural Zone of Oyo State, Nigeria. Continental J. Agricultural Economics 4: 19 25

[33] Diiro, G. (2013). Impact of Off-farm Income on Technology Adoption Intensity and Productivity Evidence from Rural Maize Farmers in Uganda. International Food Policy Research Institute, Working Paper 11.

[34] Muthoni, shimelis and Melis

[35] Gildemacher, P.R. (2012) Innovation in Seed Potato Systems in Eastern Africa. PhD Thesis, Wageningen University, Wageningen.

[36] Gaur, P. (2010) Constraints of Potato Seed Production in Developing Countries. In: Cromme N.,Prakash A.B., Lutaladio N.B. and Ezeta, F., Eds., Strengthening Potato Value Chains: Technical and Policy Options for Developing Countries, The Food and Agriculture Organization of the United Nations and the Common Fund for Commodities, Rome, 61-70.

[37] Pandey S.K. (2009) Potato Research Priorities in Asia and the Pacific Region. In: Papademetriou, M.K., Ed., Proceedings of the Workshop to Commemorate the International Year of Potato-2008, Food and Agriculture Organization of the United Nations, Regional Office for Asia and the Pacific, Bangkok, 30-39.

[38] Biniam, M.G., Githiri S.M., Tadesse, M. and Kasili, R.W. (2014) Potato Seed Supply, Marketing and Production Constraints in Eritrea. American Journal of Plant Sciences, 5, 3684-3693. http://dx.doi.org/10.4236/ajps.2014.524384.

[39] Bouis H. (2008), - Rising Food Prices will Result in Severe Declines in Mineral and Vitamin Intakes of the Poor, Harvestplus, IFPRI, Washington, D.C. 